\title{
GEOCHEMICAL ANALYSIS DATA (VOLATILE ANALYSIS SERVICE) OF CUTTINGS FOR FISH CREEK TEST WELL 1 AND SQUARE LAKE TEST WELL 1
}

Contributions by: Baker Hughes and Advanced Hydrocarbon Stratigraphy

\author{
Geologic Materials Center Data Report 470
}

GMC data reports provide analytical and interpretive data resulting from testing by third parties on material borrowed from samples housed at the Alaska Geologic Materials Center. These files are produced by the thirdparty agency or company that conducted the sampling and analysis. The results and interpretations have not undergone technical review and should not be cited as reviewed data or as an authoritative information source.

July 2020

STATE OF ALASKA

DEPARTMENT OF NATURAL RESOURCES

DIVISION OF GEOLOGICAL \& GEOPHYSICAL SURVEYS GEOLOGIC MATERIALS CENTER
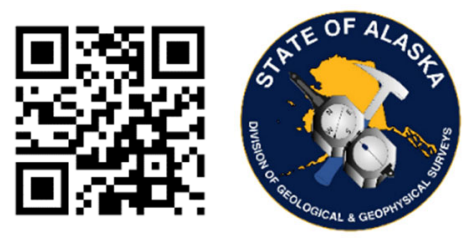
